\title{
Variability in particle retention efficiency by the mussel Mytilus edulis
}

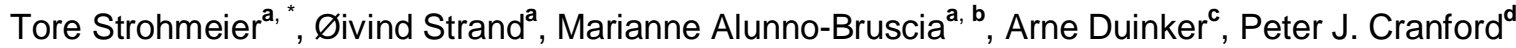

\author{
a Institute of Marine Research, PO Box 1870 Nordnes, 5817 Bergen, Norway \\ ${ }^{\mathrm{b}}$ Ifremer, 11 Presqu'île du Vivier, 29840 Argenton-en-Landunvez, France \\ ${ }^{c}$ National Institute of Nutrition and Seafood Research, PO Box 2029 Nordnes, 5817 Bergen, Norway \\ ${ }^{d}$ Fisheries and Oceans Canada, Bedford Institute of Oceanography, Dartmouth, Nova Scotia, Canada B2Y 4A2
}

*: Corresponding author : Tore Strohmeier, email address : $\underline{\text { tore.strohmeier@imr.no }}$

\begin{abstract}
:
Seasonal variation in blue mussel, Mytilus edulis, retention efficiency $(R E)$ responses to natural seston concentrations were investigated in the Lysefjord, Norway. The smallest particles shown to be effectively retained (100\%) were approximately $7 \mu \mathrm{m}$ and this was observed on only one occasion. The most common response was for $R E$ to progressively increase from small to large particles with maximum RE at 30 to $35 \mu \mathrm{m}$ (8 of 12 experiments). Temporal changes in the seston size distribution towards a dominance of smaller particles coincided with a decrease in the RE maxima to particles between 7 and $15 \mu \mathrm{m}$ diameter. The RE of $1 \mu \mathrm{m}$ and $4 \mu \mathrm{m}$ diameter particles ranged between 14$64 \%$ and $12-86 \%$, respectively, showing that small particles occasionally serve as a significant dietary component. The observed temporal variations in particle capture suggest a capacity of $M$. edulis to control particle retention mechanisms based on exogenous dietary cues that are directly or indirectly related to the ambient particle size distribution. Indirect clearance rate $(C R)$ measurements require that all particle sizes under study are effectively retained and this has widely been assumed for particles larger than $4 \mu \mathrm{m}$. CR was calculated for particles ranging in size from 5 to $35 \mu \mathrm{m}$ and the percentage reduction in $C R$, relative to particle sizes shown to be effectively retained, ranged from $11 \%$ to $87 \%$. CR calculations that included all particle counts between 5 and $35 \mu \mathrm{m}$ diameter were underestimated by a mean of $26 \%(0-48 \%$ range). Similar errors in diet characterization may be expected to affect particle selection and absorption efficiency measurements and the compounding of errors may become extreme when a number of physiological rates and efficiencies are integrated (e.g. scope for growth).
\end{abstract}

\section{Highlights}

Particle retention efficiency $(R E)$ of natural seston was investigated in $M$. edulis. The smallest particles shown to be effectively retained (100\%) were close to $7 \mu \mathrm{m}$. $\rightarrow R E$ most often increased progressively from small to large particles. Maximum $R E$ was reported at 30 to $35 \mu \mathrm{m}$ in 8 of 12 experiments. Temporal changes in particle size distribution coincided with changes in RE maxima.

Keywords: Bivalve feeding physiology; Retention efficiency; Clearance rate; Marine ecophysiology; Seston; Suspension feeding; Mytilus edulis 


\section{Introduction}

Suspension feeding bivalves molluscs carry out a significant role in the flow of energy and matter in coastal and estuarine ecosystems (Gili and Coma 1998, 1998, Newell 2004, Cranford et al. 2007). Dense populations, under some conditions, can reduce seston concentration (Dame 1996, Strohmeier et al. 2005) and change suspended particle composition (Prins et al. 1998, Maar et al. 2007, Strohmeier et al. 2008) and plankton population dynamics (Prins et al. 1998, Maar et al. 2007). The availability of food particles to suspension feeding bivalves is a function of seston concentration and size and the particle retention (capture) efficiency characteristics of feeding structures. Many studies on particle utilization by suspension feeding bivalves have employed algal cell monocultures added to filtered sea water (Vahl 1972, Møhlenberg and Riisgård 1978, Palmer and Williams 1980, Zhang et al. 2010) or have attempted to simulate natural particles by mixing microalgae, bacteria, silt and/or detritus in seawater (Kiørboe and Møhlenberg 1981, Stuart 1982, Newell and Jordan 1983, Bayne et al. 1984, Bricelj et al. 1984, Cucci et al. 1985, Shumway et al. 1985, Newell and Langdon 1986, Bayne et al. 1989). Other studies have promoted the view that ecologically relevant behaviour in bivalve suspension feeders can best be observed using natural diets (Wright et al. 1982, Newell and Jordan 1983, Stenton-Dozey and Brown 1992, Cranford et al. 1998, Cranford et al. 2005, Strohmeier et al. 2009) and this approach has become common in studies of bivalve feeding responses to the natural range of variation in particulate matter availability, chemical composition, size distribution, texture, palatability, etc.

Small particles in natural coastal waters generally dominate particle abundance and can account for a high proportion of total suspended particulate matter mass. It has been reported in numerous studies that bivalves only efficiently retain particles larger than 3 to $7 \mu \mathrm{m}$, depending on the species feeding structures (Vahl 1972, Bayne et al. 1976, Møhlenberg and Riisgård 1978, Kiørboe and Møhlenberg 1981, Lucas et al. 1987, Riisgård 1988, reviewed by Ward and Shumway 2004). In the mussel Mytilus edulis, particles larger than $4 \mu \mathrm{m}$ are reported to be retained with a nominal efficiency of $100 \%$ (Møhlenberg and Riisgård 1978) and retention efficiency rapidly declines as particle size decreases below this threshold (Møhlenberg and Riisgård 1978, Riisgård 1988). These conclusions rely on the common assumption that maximal retention occurred within the narrow particle size-range studied (generally between 1 and $10 \mu \mathrm{m}$ diameter). Dral (1967) provided early evidence of the possible regulation of particle retention by $M$. edulis through the use of non-surgical microscopic techniques and concluded that particles of at least $40 \mu \mathrm{m}$ must be used to ensure 100\% retention. Further evidence supporting the concept of variable retention efficiency comes from field studies on bivalves feeding on natural seston. Lucas et al. (1987), Cranford and Gordon (1992), Stenton-Dozey and Brown (1992) and Barillé et al. (1993) measured 100\% retention efficiency for 16, 40, 23 and $12 \mu \mathrm{m}$ diameter particles, respectively. The results of these studies suggest that effective particle capture is not determined solely by the sieving properties of the gill. The ability of bivalves to alter particle capture efficiency, the factors controlling this response, and the temporal scale over which bivalves control particle capture has been described as a "fertile area for future research" (Ward and Shumway 2004).

Accurate characterization of particle retention efficiency is fundamental to the calculation of clearance rate (the volume of water cleared of particles of a given size per unit time): a principle physiological function in the modulation of energy acquisition in suspension feeding bivalves (Hawkins et al. 1999, Gardner and Thompson 2001, Hawkins et al. 2001, Cranford et al. 2005, Strohmeier et al. 2009). The application of all the indirect methodologies that are currently the primary means for measuring clearance rate requires that particle removal by bivalves from a closed or flow-through suspension is known to be $100 \%$ efficient (Coughlan 1969). The capacity of bivalves to capture available food particles must also be accounted for in absorption efficiency methodologies that require the characterization of absorbed and conservative tracers in food 
and faeces (Conover 1966). Accurate information on food retention efficiency is therefore critical to estimating all energy gain parameters within the bivalve energy budget and is also linked to the accuracy of eco-physiological and ecosystem model predictions with dense bivalve communities and aquaculture carrying capacity (Grant et al. 2008, Grangeré et al. 2010).

In the present study we revisited the topic of particle retention efficiency in $M$. edulis to investigate the theory of variable particle size capture in nature. Information on the seasonal distribution, abundance and quality of natural food particles was collected in conjunction with mussel retention efficiency and clearance rate measurements to aid in identifying potential factors contributing to variations in food acquisition responses and to examine changes in retention efficiency across spatial and temporal scales.

\section{Materials and methods}

Retention efficiency (RE) measurements for blue mussels exposed to natural seston concentrations were obtained from two experimental sites in Lysefjord from 19 May to 25 August, 2010. RE was determined on six dates at each station. Lysefjord is located on the southwest coast of Norway ( $58^{\circ} 56^{\prime}, \mathrm{E} 6^{\circ} 8^{\prime}$ ) and is approximately $40 \mathrm{~km}$ long and 0.5 - $2 \mathrm{~km}$ wide with a depth range from 13 meters at the outer sill to a maximum depth of 460 meters. The mean tidal range is $0.4 \mathrm{~m}$. The experiments were conducted on the sites; Måkasteinen (MS) near the head of the fjord and Flørli (FL), located $14 \mathrm{~km}$ seaward of MS.

Mussels from the 2008 cohort were harvested from suspended aquaculture ropes in Lysefjord, graded to a shell length range of $45-50 \mathrm{~mm}$ (mean $47 \mathrm{~mm}$ ) and transported to the experimental sites at MS and FL on 2 March, 2010. Two groups of 40 mussels were individually marked, and 20 mussels from each group were used to determine RE. The mussels were held in lantern nets suspended from a long-line at $7 \mathrm{~m}$ depth for the duration of the study.

Temperature and salinity were measured simultaneously at both sites at 30 min intervals during the study using a CTD instrument (SAIV A/S Model 204, Norway) that was moored at the holding depth of the mussels. Water samples for seston analysis were collected from the same depth at biweekly intervals. Suspended particulate matter and particulate organic matter (SPM and POM; $\mathrm{mg} \mathrm{l}^{-1}$ ) were determined in triplicate for seston filtered onto pre-washed (distilled water), ashed, and tared $1.2 \mu \mathrm{m}$ nominal pore size filters (Whatman GF/C). Salt was expelled from samples by rinsing each filter under vacuum with isotonic ammonium formate. Filters were then dried at $60^{\circ} \mathrm{C}$ over night and weighed to $\pm 0.01 \mathrm{mg}$ to calculate SPM. The filters were then burned at $450^{\circ} \mathrm{C}$ and reweighed for the calculation of inorganic content and POM concentration. Particle numbers (counts) and size-distribution in water samples were determined using a Pamas $\mathrm{GmbH}$ field laser particle counter (Model S4031GO) as described below for determination of $R E$. Particle volume was then calculated under the assumption that particles in all size-ranges were spherical.

Chlorophyll a $(\mathrm{Chl} \mathrm{a)} \mathrm{concentrations} \mathrm{were} \mathrm{determined} \mathrm{on} \mathrm{the} \mathrm{same} \mathrm{days} \mathrm{as} \mathrm{SPM} \mathrm{samples} \mathrm{by}$ filtering seston (0.5 I) onto a $1.2 \mu \mathrm{m}$ filter (Whatman GF/C). Chl a was analysed after extraction with $90 \%$ acetone using the fluorescence method with correction for acidified measurements (Strickland and Parson 1968). The fluorometer (Turner Designs Model 10-AU) was calibrated with known concentrations of Chl a (Sigma Chemicals, St. Louis, Mo., USA).

Mussel feeding experiments were conducted using the flow-through method. The feeding chambers were similar in design to those reported by Palmer and Williams (1980), but without the angular baffle in the middle of the chamber. The internal dimensions of the mussel chambers were $3.8 \mathrm{~cm}$ wide, $19.5 \mathrm{~cm}$ long and $8.1 \mathrm{~cm}$ deep. This chamber design constrains recirculation and prevents refiltration of water by the bivalves when an acceptable flow speed is provided (previously determined for similar sized mussels by Strohmeier et al. 2009). On each sampling 
date, RE was measured by temporally transferring 20 individually marked mussels from the holding net to separate flow-through chambers. The bivalves were returned to the net after determination of RE. Two additional chambers were left empty to control for any effect the chamber may have on the outflow particle concentration. The bivalves were left undisturbed in chambers with flowing seawater at least $0.5 \mathrm{~h}$ to resume feeding before sampling water from the outlet of the chambers. Water samples collected from each chamber outlet were analysed for particle concentration and size-distribution using the Pamas particle analyzer. The analyzer was calibrated before the experiment and set to count particles spanning a total range from 1 to 35 $\mu \mathrm{m}$ (sizes channels: 1, 1.5, 2, 2.5, 3, 4, 5, 6, 7, 8, 9, 10, 11, 12, 13, 14, 15, 16, 17, 18, 19, 20, $21,22,25,30$ and $35 \mu \mathrm{m})$. Each water sample comprised three sub-samples, in which particles were counted in $10 \mathrm{ml}$ of seawater. The mean particle count was used to calculate the RE per size class for each individual according to the following equation:

$$
R E=1-\left(\mathrm{PC}_{\mathrm{B}} / \mathrm{PC}_{\mathrm{C}}\right), \quad \text { Equation } 1
$$

where $P C_{C}$ is particle count exiting the control chamber and $P_{B}$ is particle count exiting the bivalve chamber. RE was calculated for all 27 particle size channels for each bivalve and was replicated for 20 individual bivalves on each sampling date. RE data for each individual were then standardized by setting the $R E$ in the particle size cleared at the highest efficiency to $100 \%$ and then scaling $R E$ in the other size-classes proportionately. Standardization was performed for each individual before averaging across the 20 individuals to give the mean cohort RE response for each particle size class. This standardization procedure is widely utilized (e.g. Riisgård 1988) to constrain the effect of inter-individual feeding rates on $R E$.

Clearance rate $(C R)$ was calculated for each individual as;

$$
C R=R E * F,
$$

Equation 2

where the RE measurements are non-standardised and $F$ is the flow rate $\left(\mathrm{h} \mathrm{h}^{-1}\right)$ measured at the outlet of each chamber. The $F$ to each chamber was typically $10-15 \mathrm{I} \mathrm{h}^{-1}$, giving estimated current speeds in chambers at $0.2 \mathrm{~cm} \mathrm{~s}^{-1}$. CR was calculated separately using $R E$ calculations for individual particle size classes $(5,10,20$ and 30) and for total particle counts between 5 and $35 \mu \mathrm{m}$ diameter.

Statistical tests were performed at $\alpha=0.05$ with Statistica Version 9.1 (StatSoft, Ink 2010). The same group of animals from each site was used on each date so repeated measures ANOVAs were used to test for differences in mean RE across all sampling dates (date was the dependent variable and particle size was the categorical predictor) and between the two sites. Only whole numbers of particle sizes were used in the statistical analysis (i.e. 25 size channels) in this balanced $n$ design ( $n=20$ individual mussels for the six dates). Homogeneity of variances among retention efficiency and time was evaluated using Greenhouse-Geisser's and HuynhFeldt epsilon indices for repeated measures (Latour and Miniard 1983). Cases of a significant ANOVA result were followed by a Tukey HSD post hoc test (Zar 1996).

\section{Results}

Water temperature at the holding depth of the mussels increased gradually from $8^{\circ} \mathrm{C}$ in May to $16^{\circ} \mathrm{C}$ in August. Salinity remained at $29-30$ psu (SD $=2.3$ ) over the same period. The number of particles in seawater decreased exponentially from 1 to $35 \mu \mathrm{m}$ at both sites (Fig. 1). Although particle volume (PV) measured within the instrument's $1 \mu \mathrm{m}$ particle-size bin constituted an insignificant fraction of the total particle volume (range $=0.1 \%$ to $0.9 \%$ ), particle volumes within the $4 \mu \mathrm{m}$ size-class were often high (Fig. 2). Seston particle volumes at both sites tended to be 
evenly spread out across a wide size-range in May to mid-June and thereafter became increasingly dominated by 2.5 to $10 \mu \mathrm{m}$ particles (Fig. 2). By late August, $4 \mu \mathrm{m}$ particles dominated particle concentration at both sites. Seston concentration (SPM and Chl a) was typically higher at MS compared to FL, while the seston quality (POM\%) was similar at both sites (Table 1).

The RE of 1 and $4 \mu \mathrm{m}$ diameter particles by $M$. edulis ranged between 14 to $43 \%$ and 12 to $68 \%$, respectively (Fig. 3). Variations in standardized $R E$ between individual mussels resulted in average values not reaching 100\%. When the average data shown in Fig. 3 are standardized again using the same procedure, then $14-64 \%$ of $1 \mu \mathrm{m}$ particles, and $12-86 \%$ of $4 \mu \mathrm{m}$ particles are retained. The smallest particles shown to be effectively retained (100\%) were approximately $7 \mu \mathrm{m}$ and this only occurred on one occasion (Fig. 3; MS site on 10 August). The most common response was for $R E$ to progressively increase from small to large particles with maximum $R E$ at 30 to $35 \mu \mathrm{m}$ (Fig. 3; 8 of 12 dates). On three occasions, maximum RE was observed for particles less than $30 \mu \mathrm{m}$ (Fig. 3). Results from repeated measures ANOVA followed by Tukey post hoc tests provide statistical support for all these observations by identifying the particle size-ranges over which the $R E$ response was significantly higher relative to other available size-classes (Table 2 and 3).

To examine $R E$ of a narrow particle size range, which has been the common practice (see Introduction), RE was standardized on particle sizes in the range from 1 to $10 \mu \mathrm{m}$. ANOVA and Tukey tests on these data indicate that the RE of $5 \mu \mathrm{m}$ particles was not significantly different than for larger particles in 7 of the 12 experiments (Tables 4 and 5).

Mussels exhibited significant differences in mean standardized $R E$ across sampling dates (Table 2; $p<0.001$ ). Measurements conducted in May and June showed RE maxima between 22 and $35 \mu \mathrm{m}$, while all four experiments conducted in August showed elevated and/or maximum RE in smaller size ranges (Fig. 3; Table 3) that correspond with the relatively larger contribution of small particle volumes (3.5 to $8 \mu \mathrm{m}$ ) in August (Fig. 2).

Mussel clearance rate $(C R)$ results shown in Figure 4 are based on narrow particle size ranges $(5,10,20$, and $30 \mu \mathrm{m})$ and across a wider size range (5 to $35 \mu \mathrm{m}$ particles). Average $C R$ estimates were highest when the $R E$ assumption fulfilled the methodological assumption of $C R$ estimates (identified in Figure 4). Otherwise, the percentage reduction in $C R$ ranged from $11 \%$ to $87 \%$. The $C R$ estimated for all particles ranging from 5 to $35 \mu \mathrm{m}$ displayed intermediate error values ( 0 to $48 \%$ reduction) with $C R$ being underestimated by a mean of $26 \%$. CR estimates (mean $\pm \mathrm{SD}$ ) on mussels showing maximal $R E$ were higher at the FL $\left(5.1 \pm 1.0 \mathrm{I} \mathrm{h}^{-1}\right.$ ind $\left.^{-1}\right)$ site than at MS $\left(3.6 \pm 2.0 \mathrm{I} \mathrm{h}^{-1}\right.$ ind $\left.^{-1}\right)$ over the duration of this study.

\section{Discussion}

Our results on temporal and spatial variations in particle capture by the mussel Mytilus edulis indicate the capacity of this species to modulate the retention efficiency of natural seston particles in relation to seasonal availability in trophic resources. These results confirm previous, albeit limited, observations that have suggested that the effective retention efficiency of bivalves provided natural seston can exceed the commonly accepted norm of $4 \mu \mathrm{m}$ particle diameter (Lucas et al. 1987, Cranford and Gordon 1992, Stenton-Dozey and Brown 1992, Barillé et al. 1993). In addition we clearly demonstrate that the retention efficiency of different particle sizes is not constant as is widely reported, but varies spatially and seasonally and possibly in direct response to changes in the seston.

It is recognized that the notion of variable retention efficiency in $M$. edulis is contrary to widely accepted beliefs in the field of bivalve ecophysiology. The authors were initially sceptical of the results and subsequently assessed many possible sources of methodological error that may have influenced our conclusions. Additional views on this topic were expressed by the reviewers. 
First, errors in particle counting methodologies or instrument calibration would obviously lead to erroneous RE results, but established technologies and calibration methodologies were employed to provide accurate data. A high level of replication (20 mussels per treatment) was also employed in this study to constrain inter-individual feeding variability and maximize $R E$ estimate precision. Second, the $R E$ standardization procedure was rejected as a possible source of error because it does not change the shape of the RE vs. particle size curve or maximum RE, but is required to remove any inter-individual feeding rate effects on $R E$. This is the same standardization approach utilized in all the cited papers on this topic. Third, possible effects on $R E$ of flow rate variations through the chambers were excluded given that flow rate was controlled to an essentially constant value. Fourth, the mussels may have been exposed to a flocculated diet that is not adequately characterized by most particle counting technologies and can influence bivalve feeding (Cranford et al. 2005). If the mussels were retaining large flocs as opposed to the individual particle constituents, then the reported RE results would be in error. A ubiquitous property of marine aggregates is that they are highly fragile and readily dispersed by even the most gentle of sampling techniques. Pumping water to the experimental chambers is expected to disperse any flocs. Also, if the mussels were retaining flocs, the retention of fine particles would increase relative to the results of studies on individual particle capture, whereas we report relatively low $R E$ values for fine particles. We show that the most probable methodological obstacle is in confining $R E$ measurements to a narrow size range (e.g. 1 to 10 $\mu \mathrm{m}$ ) that erroneously assumes that maximum RE will occur within that range (Tables 4 and 5). The present study was conducted for a relatively narrow range of dietary conditions (relatively low seston diet) compared with those existing across the biogeographic distribution of mussels. The capacity for variable particle retention efficiency needs to be studied at additional sites and particularly under higher seston concentrations where higher suspended particle loads may limit this behaviour.

The standardized retention efficiency size-distribution was generally skewed towards the capture of relatively large particles, despite the fact that the ctenidium is capable of effectively retaining 4 $\mu \mathrm{m}$ particles and, to a lesser extent, sub-micron particles (reviewed by Ward and Shumway 2004). Small particles dominated particle counts of the natural seston and the mussels were able to retain $14-64 \%$ of $1 \mu \mathrm{m}$ particles. Although the volume of $4 \mu \mathrm{m}$ particles typically comprised a significant fraction of the available seston (Fig. 2), their capture efficiency was generally less than $40 \%$ (Fig. 3). However, it is notable that during late summer, when $4 \mu \mathrm{m}$ particles contributed most to the total particle volume, the $R E$ exceeded $50 \%$ with a maximum $R E$ of $84 \%$. During May and June, when abundant particle volumes included most sizes between 3 and $35 \mu \mathrm{m}$, mussels most effectively retained particles larger than 20 to $30 \mu \mathrm{m}$ (Table 3). In contrast, as the particle spectra shifted towards the dominance of smaller particle volumes in late July and August, maximal retention shifted to particles between 6 and $16 \mu \mathrm{m}$ (Table 3). In all cases, maximal retention was confined to a relatively narrow size range (Fig. 3 ). These data clearly indicate a capacity of $M$. edulis to substantially control particle retention mechanisms, likely in response to exogenous dietary factors.

Laboratory studies have suggested that factors in addition to particle size can influence particle capture by bivalves (see review by Ward \& Shumway 2004). It has been shown that specific phytoplankton can be selectively captured from a suspension containing several species of similar sized cells (Shumway et al. 1985, Shumway et al. 1997). Bivalves have been observed to preferentially capture fluorescent particles relative to non-fluorescent particles (Newell et al. 1989) and phytoplankton instead of silt or clay (Cranford and Gordon 1992, Newell and Shumway 1993). The observed trait of mussels to increase the capture efficiency of intermediate size particles, or to reduce the retention efficiency of larger particles (Fig. 3) is supported by literature on differential particle capture and clearance rates of mussels (Bayne and Scullard 1977, Pile and Young 1999, Trottet et al. 2008), scallops (Lesser et al. 1991) and oysters (Bougrier et al. 1997, Pouvreau et al. 1999). 
Variable capture efficiency may, to some extent, be controlled by adjusting the interfilamentary spaces of the ctenidium (Palmer and Williams 1980, Cranford and Gordon 1992, Barillé et al. 1993), and by adjusting the movement and coordination of the latero-frontal cilia (Dral 1967). In addition, Ward and Shumway (2004) suggested that "enhanced particle retention could be a consequence of specific interactions between the extracellular matrix of living cells, and cilia and mucus of the bivalve ctenidia". They also noted that "smaller particles may be captured more efficiently than larger particles as a result of differences in cell shape, flexibility, or swimming ability". Stenton-Dozey and Brown (1992) suggested that the shift in efficiency of particle capture that they observed over a tidal cycle coincided with an increase in the size range of particles that contained the greatest organic content (i.e. optimize organic intake). We did not address this possibility in the present study, but changes in the composition of particles may also be associated with the observed temporal changes in the particle volume spectra that coincided with enhanced particle retention in Lysefjord.

The diversity of evidence presented above contradicts the traditional view that particle capture is merely a mechanical sieving process by the laterofrontal ciliary tracts that results in retention efficiency increasing non-linearly with increasing particle size to a maximum at approximately 4 to $7 \mu \mathrm{m}$ particles. However, this size threshold has become engrained within the bivalve ecophysiology literature with potentially negative consequences for the accurate measurement of all physiological parameters (rates and efficiencies) describing energy gain. The relative ease of indirectly measuring bivalve clearance rate (Coughlan 1969) using a variety of apparatus (Riisgård 2001) has contributed to a prolific literature (reviewed by Cranford et al. 2011) and requires that a known fixed percentage of particles are retained (100\%) by the bivalve gill. With few exceptions, this value has been assumed to be close to the 4-7 $\mu \mathrm{m}$ range. It appears that these values are the consequence of only considering a relatively narrow particle size range (1 to $10 \mu \mathrm{m})$. In the present study when effective particle capture occurred outside this range, clearance rates were underestimated by 11 to $87 \%$ (Fig. 4).

Filtration rate calculations, post-capture selection efficiency, ingestion rate, and absorption efficiency and rate measurements are all prone to similar errors because the available methodologies assume that food particles captured, ingested and digested can be accurately characterized by using some type of filter that approximately mimics the same particle capture properties as the bivalve. This approach can be accurate when RE is known to decline rapidly below particle sizes that are effectively captured. However, the natural particle retention sizespectra observed for mussels in the present study (Fig. 3) cannot be replicated by glass fibre filter, or other membrane filters. The compounding of errors may become extreme when a number of physiological rates and efficiencies are integrated (e.g. scope for growth). Problems with diet characterization will also make it difficult to develop predictive relationships between bulk dietary properties (SPM, POM\%, Chl a) and physiological functions given that these properties will often vary across the range of ambient particle sizes. Size-fractionation of the seston may be a possible solution for more accurately characterizing bivalve food quantity and quality in nature. We emphasize the need to carefully consider the actual retention efficiency of the bivalves under study when measuring diet availability and composition and recommend more rigorous testing of methodological assumptions related to particle retention when performing physiological measurements with suspension-feeding bivalves in the laboratory and in nature.

\section{Acknowledgments}

This project was funded by the Research Council of Norway (project no 196560/540). We thank the reviewers for their helpful comments on the manuscript. 


\section{References}

Barillé, L., Prou, J., Héral, M., Bougrier, S. (1993) No influence of food quality, but rationdependent retention efficiencies in the japanese oyster Crassostrea-gigas. J Exp Mar Biol Ecol 171:91-106

Bayne, B.L., Bayne, C.J., Carefoot, T.C., Thompson, R.J. (1976) Physiological ecology of Mytilus californianus Conrad. 1. Metabolism and energy-balance. Oecologia 22:211-228

Bayne, B.L., Hawkins, A.J.S., Navarro, E., Iglesias, I.P. (1989) Effects of seston concetration on feeding, digestion and growth in the mussel Mytilus edulis. Mar Ecol Prog Ser 55:47-54

Bayne, B.L., Klumpp, D.W., Clarke, K.R. (1984) Aspects of feeding, including estimates of gut residence time, in three Mytilid species (Bivalvia, Mollusca) at two contrasting sites in the Cape Penninsula, South-Africa. Oecologia 64:26-33

Bayne, B.L., Scullard, C. (1977) Apparent specific dynamic action in Mytilus edulis L. J Mar Biol Assoc United Kingdom 57:371-378

Bougrier, S., Hawkins, A.J.S., Héral, M. (1997) Preingestive selection of different microalgal mixtures in Crassostrea gigas and Mytilus edulis, analysed by flow cytometry. Aquaculture 150:123-134

Bricelj, V.M., Malouf, R.E., Dequillfeldt, C. (1984) Growth of juvenile Mercenaria mercenaria and the effect of resuspended bottom sediments Mar Biol 84:167-173

Conover, R.J. (1966) Assimilation of organic matter by zooplankton. Limnol. Oceanog. 11:338345

Coughlan, J. (1969) Estimation of filtering rate from clearance of suspensions. Mar Biol 2:356358

Cranford, P.J., Annsworthy, S.L., Mikkelsen, O.A., Milligan, T.G. (2005) Food acquisition responses of the suspension-feeding bivalve Placopecten magellanicus to the flocculation and settlement of a phytoplankton bloom. J Exp Mar Biol Ecol 326:128-143

Cranford, P.J., Emerson, C.W., Hargrave, B.T., Milligan, T.G. (1998) In situ feeding and absorption responses of sea scallops Placopecten magellanicus (Gmelin) to storm-induced changes in the quantity and composition of the seston. J Exp Mar Biol Ecol 219:45-70

Cranford, P.J., Gordon, D.C. (1992) The influence of dilute clay suspensions on sea scallop (Placopecten magellanicus) feeding-activity and tissue-growth. Netherlands Inst Sea Res, p 107120

Cranford, P.J., Strain, P.M., Dowd, M., Hargrave, B.T., Grant, J., Archambault, M.C. (2007) Influence of mussel aquaculture on nitrogen dynamics in a nutrient enriched coastal embayment. Mar Ecol Prog Ser 347:61-78

Cranford, P.J., Ward, J.E., Shumway, S.E. (2011) Bivalve filter feeding: variability and limits of the aquaculture biofilter. In: Shumway, S.E. (ed.) Shellfish aquaculture and the environment. Wiley-Blackwell, Hoboken, NJ.

Cucci, T.L., Shumway, S.E., Newell, R.C., Selvin, R., Guillard, R.R.L., Yentsch, C.M. (1985) Flow-cytometry -a new method for characterization of differential ingestion, digestion and egestion by suspension feeders. Mar Ecol Prog Ser 24:201-204

Dame, R.F. (1996) Ecology of marine bivalves: an ecosystem approach, CRC Press, Boca Raton

Dral, A.D.G. (1967) The movements of the latero-frontal cilia and the mechanism of particle retention in the mussel (Mytilus edulis L.). Netherlands J Sea Res 3:391-422

Gardner, J.P.A., Thompson, R.J. (2001) Naturally low seston concentration and the net energy balance of the greenshell mussel (Perna canaliculus) at Island Bay, Cook Strait, New Zealand. New Zealand J Mar Freshwater Res 35:457-468

Gili, J.M., Coma, R. (1998) Benthic suspension feeders: their paramount role in littoral marine food webs. Trends Ecol Evol 13:316-321 
Grangeré, K., Lefebvre, S., Bacher, C., Cugier, P., Ménesguen, A. (2010) Modelling the spatial heterogeneity of ecological processes in an intertidal estuarine bay: dynamic interactions between bivalves and phytoplankton. Mar Ecol Prog Ser 415:141-158

Grant, J., Bacher, C., Cranford, P.J., Guyondet, T., Carreau, M. (2008) A spatially explicit ecosystem model of seston depletion in dense mussel culture. J Mar Systems 73:155-168

Hawkins, A.J.S., Fang, J.G., Pascoe, P.L., Zhang, J.H., Zhang, X.L., Zhu, M.Y. (2001) Modelling short-term responsive adjustments in particle clearance rate among bivalve suspension-feeders: separate unimodal effects of seston volume and composition in the scallop Chlamys farreri. J Exp Mar Biol Ecol 262:61-73

Hawkins, A.J.S., James, M.R., Hickman, R.W., Hatton, S., Weatherhead, M. (1999) Modelling of suspension-feeding and growth in the green-lipped mussel Perna canaliculus exposed to natural and experimental variations of seston availability in the Marlborough Sounds, New Zealand. Mar Ecol Prog Ser 191:217-232

Kiørboe, T., Møhlenberg, F. (1981) Particle selection in suspension-feeding bivalves. Mar Ecol Prog Ser 5:291-296

Latour, S.A., Miniard, P.W. (1983) The misuse of repeated measures analysis in marketingresearch. J Mark Res 20:45-57

Lesser, M.P., Shumway, S.E., Cucci, T., Barter, J., Edwards, J. (1991) Size specific selection of phytoplankton by juvenile filter-feeding bivalves: Comparison of the sea scallop Placopecten magellanicus (Gmelin, 1791) with Mya arenaria (Linnaeus, 1758) and Mytilus edulis (Linnaeus, 1758). In: Shumway SE, Sandifer PA (eds) An international compendium of scallop biology and culture. World Aquaculture Society

Lucas, M.I., Newell, R.C., Shumway, S.E., Seiderer, L.J., Bally, R. (1987) Particle clearance and yield in relation to bacterioplankton and suspended particulate availability in estuarine and open coast populations of the mussel Mytilus edulis. Mar Ecol Prog Ser 36:215-224

Maar, M., Nielsen, T.G., Bolding, K., Burchard, H., Visser, A.W. (2007) Grazing effects of blue mussel Mytilus edulis on the pelagic food web under different turbulence conditions. Mar Ecol Prog Ser 339:199-213

Møhlenberg, F., Riisgård, H.U. (1978) Efficiency of particle retention in 13 species of suspension feeding bivalves. Ophelia 17:239-246

Newell, C.R., Shumway, S.E. (1993) Grazing of natural particulates by bivalve molluscs: A spatial and temporal perspective. In. Dame RF (ed) Bivalve filter feeders in estuarine and coastal ecosystem. Springer Berlin, pp 85-148

Newell, C.R., Shumway, S.E., Cucci, T.L., Selvin, R. (1989) The effect of natural seston particle size and type on feeding rates, feeding selectivity and food resource availability for the mussel Mytilus edulis (Linnaeus, 1758) at bottom culture sites. J Shellfish Res 8:187-196

Newell, R.I.E. (2004) Ecosystem influences of natural and cultivated populations of suspensionfeeding bivalve molluscs: A review. J Shellfish Res 23:51-61

Newell, R.I.E., Jordan, S.J. (1983) Preferential ingestion of organic material by the American oyster Crassostrea virginica. Mar Ecol Prog Ser 13:47-53

Newell, R.I.E., Langdon, C.J. (1986) Digestion and absorption of refractory carbon from the plant Spartina alterniflora by the oyster Crassostrea virginica. Mar Ecol Prog Ser 34:105-115

Palmer, R.E., Williams, L.G. (1980) Effect of particle concentration on filtration efficiency of the bay scallop Argopecten irradians and the oyster Crassostrea virginica. Ophelia 19:163-174

Pile, A.J., Young, C.M. (1999) Plankton availability and retention efficiencies of cold-seep symbiotic mussels. Limnol Oceanogr 44:1833-1839

Pouvreau, S., Jonquières, G., Buestel, D. (1999) Filtration by the pearl oyster, Pinctada margaritifera, under conditions of low seston load and small particle size in a tropical lagoon habitat. Aquaculture 176:295-314

Prins, T.C., Smaal, A.C., Dame, R.F. (1998) A review of the feedbacks between bivalve grazing and ecosystem processes. Aquatic Ecol 31:349-359 
Riisgård, H.U. (1988) Efficiency of particle retention and filtration-rate in 6 species of northeast American bivalves. Mar Ecol Prog Ser 45:217-223

Riisgård, H.U. (2001) On measurement of filtration rates in bivalves - the stony road to reliable data: Review and interpretation. Mar Ecol Prog Ser 211:275-291

Shumway, S.E., Cucci, T.L., Lesser, M.P., Bourne, N., Bunting, B. (1997) Particle clearance and selection in three species of juvenile scallops. Aquaculture Internat 5:89-99

Shumway, S.E., Cucci, T.L., Newell, R.C., Yentsch, C.M. (1985) Particle selection, ingestion, and absorption in filter-feeding bivalves. J Exp Mar Biol Ecol 91:77-92

Stenton-Dozey, J.M.E., Brown, A.C. (1992) Clearance and retention efficiency of natural suspended particles by the rock-pool bivalve Venerupis corrugatus in relation to tidal availability. Mar Ecol Prog Ser 82:175-186

Strickland, J.D.H., Parson, T.R. (1968) A practical handbook of seawater analysis. Bull Fish Res Can 167:1-311

Strohmeier, T., Aure, J., Duinker, A., Castberg, T., Svardal, A., Strand, Ø. (2005) Flow reduction, seston depletion, meat content and distribution of diarrhetic shellfish toxins in a long-line blue mussel (Mytilus edulis) farm. J Shellfish Res 24:15-23

Strohmeier, T., Duinker, A., Strand, $\varnothing$., Aure, J. (2008) Temporal and spatial variation in food availability and meat ratio in a longline mussel farm (Mytilus edulis). Aquaculture 276:83-90

Strohmeier, T., Strand, $\varnothing$., Cranford, P. (2009) Clearance rates of the great scallop (Pecten maximus) and blue mussel (Mytilus edulis) at low natural seston concentrations. Mar Biol 156:1781-1795

Stuart, V. (1982) Absorbed ration, respiratory cost and resultant scope for growth in the mussel Aulacomya ater (molina) fed on a diet on kelp detritus of different ages. Mar Biol Letters 3:289306

Trottet, A., Roy, S., Tamigneaux, E., Lovejoy, C., Tremblay, R. (2008) Impact of suspended mussels (Mytilus edulis L.) on plankton communities in a Magdalen islands lagoon (Québec, Canada): A mesocosm approach. J Exp Mar Biol Ecol 365:103-115

Vahl, O. (1972) Efficiency of particle retention in Mytilus edulis L. Ophelia 10:17-25

Ward, J.E., Shumway, S.E. (2004) Separating the grain from the chaff: particle selection in suspension- and deposit-feeding bivalves. J Exp Mar Biol Ecol 300:83-130

Wright, R.T., Coffin, R.B., Ersing, C.P., Pearson, D. (1982) Field and laboratory measurements of bivalve filtration of natural marine bacterioplankton. Limnol Oceanogr 27:91-98

Zar, J.H. (1996) Biostatistical analysis. Prentice Hall, Upper Saddle River, p 662

Zhang, J.H., Fang, J.G., Liang, X.M. (2010) Variations in retention efficiency of bivalves to different concentrations and organic content of suspended particles. Chinese $\mathrm{J}$ Oceanol Limn 28:10-17 


\section{Tables}

Table 1. Time-series of bulk seston characteristics from $7 \mathrm{~m}$ depth sampled during the feeding experiments with Mytilus edulis at Måkasteinen (MS) and Flørli (FL). PV = total particle volume between 1 and $35 \mu \mathrm{m}$ diameter, SPM = suspended particulate matter, POM = particulate organic matter, $\mathrm{POM}=$ organic content of the seston and $\mathrm{Chl} \mathrm{a}=$ chlorophyll $\mathrm{a}$. Number in parenthesis represent $\pm 95 \%$ confidence limits.

\begin{tabular}{|c|c|c|c|c|c|c|}
\hline Site & Date & $\mathrm{PV}\left(\mathrm{mm}^{3} \mathrm{I}^{-1}\right)$ & $\operatorname{SPM}\left(\mathrm{mg} \mathrm{l}^{-1}\right)$ & $\operatorname{POM}\left(\mathrm{mg} \mathrm{l}^{-1}\right)$ & POM (\%) & Chl a $\left(\mu \mathrm{g} \mathrm{I}^{-1}\right)$ \\
\hline MS & May 20 & 2.90 & $1.6(0.95)$ & $0.8(0.33)$ & 52 & 4.4 \\
\hline MS & June 1 & 7.07 & $4.2(0.64)$ & $2.1(0.31)$ & 50 & 5.8 \\
\hline MS & June 15 & 9.19 & $4.6(1.10)$ & $2.4(0.65)$ & 54 & 6.2 \\
\hline MS & June 29 & 3.84 & $3.5(0.85)$ & $1.8(0.39)$ & 52 & 3.1 \\
\hline MS & Aug. 10 & 1.59 & $1.7(1.74)$ & $0.9(0.49)$ & 54 & 2.0 \\
\hline MS & Aug. 24 & 0.83 & $1.9(0.91)$ & $1.0(0.31)$ & 53 & 1.6 \\
\hline $\mathrm{FL}$ & May 19 & 4.22 & * & * & $\star$ & 1.0 \\
\hline FL & June 2 & 2.93 & 3.2 (1.69) & $1.6(0.59)$ & 51 & 2.4 \\
\hline FL & June 14 & 4.16 & 3.5 (1.69) & $1.7(0.33)$ & 47 & 2.4 \\
\hline FL & June 29 & 2.30 & $2.4(0.85)$ & $1.3(0.39)$ & 53 & 1.0 \\
\hline FL & Aug. 11 & 1.53 & $\mathrm{Na}$ & $\mathrm{Na}$ & $\mathrm{Na}$ & 1.2 \\
\hline $\mathrm{FL}$ & Aug. 25 & 0.67 & * & * & * & 1.2 \\
\hline
\end{tabular}


Table 2. Summary results from repeated measures ANOVA testing overall differences in Mytilus edulis mean retention efficiency of particles between 1 and $35 \mu \mathrm{m}$ and across sampling dates. Separate ANOVA were conducted for data from the Måkasteinen (MS) and Flørli (FL) sampling sites.

\begin{tabular}{llllllll} 
Site & Effect & SS & df & MS & $\boldsymbol{F}$ & $\begin{array}{l}\text { G-G } \\
\text { epsilon }\end{array}$ & $\boldsymbol{H}$ - $\boldsymbol{p}$ \\
\hline MS & Intercept & 18614883 & 1 & 18614883 & 11527 & & 0.001 \\
& Date & 429480 & 5 & 85896 & 119 & $0.74 / 0.74$ & $0.001 / 0.001 * / 0.001$ ** \\
FL & Intercept & 7714825 & 1 & 7714825 & 2652 & & 0.001 \\
& Date & 245056 & 5 & 49011 & 116 & $0.76 / 0.77$ & $0.001 / 0.001 * / 0.001$ ** \\
\hline
\end{tabular}

*Greenhouse-Geiser's and **Huynh-Feldt's epsilon for homogeneity with adjusted $p$ values for repeated measures ANOVA

Table 3. Tukey post hoc test results examining the mean effect of particle size (1 to $35 \mu \mathrm{m}$ ) on Mytilus edulis maximum retention efficiency (RE) at Måkasteinen (MS) and Flørli (FL). ANOVA test results summarized in Table 2; $p<0.001$. The particle size in which the mean $R E$ is significantly greater than for smaller and/or larger particles is indicated in bold. For example, 1$18<22>35$ shows the RE of $22 \mu \mathrm{m}$ were significantly higher compared to particles between 1-18 $\mu \mathrm{m}$ and for $35 \mu \mathrm{m}$ particles. MS is the error term between particle sizes while the error term within date (pooled MS) was $596(d f=5231)$ and $491(d f=1938)$ at MS and FL, respectively.

\begin{tabular}{llllll}
\hline Site & Date & $\boldsymbol{R E}(\boldsymbol{\mu m})$ & MS & $\boldsymbol{d f}$ & Tukey $\boldsymbol{p}$ \\
\hline MS & May 20 & $1-18<\mathbf{2 2}>35$ & 166 & 912 & 0.021 \\
MS & June 1 & $1-22<\mathbf{3 0}$ & 604 & 912 & 0.003 \\
MS & June 15 & $1<\mathbf{3 5}$ & 1130 & 912 & 0.016 \\
MS & June 29 & $1-22<\mathbf{3 5}$ & 48 & 912 & $<0.001$ \\
MS & Aug. 10 & $1-2<\mathbf{6 - 1 2 > 2 1 - 3 5}$ & 746 & 912 & 0.040 \\
MS & Aug. 24 & $1<\mathbf{1 2 - 1 5 > 2 0 - 2 2 ~}$ & 883 & 912 & 0.018 \\
\hline FL & May 19 & $1-30<\mathbf{3 5}$ & 232 & 745 & 0.003 \\
FL & June 2 & $1-22<\mathbf{3 5}$ & 377 & 475 & $<0.001$ \\
FL & June 14 & $1-17<\mathbf{3 5}$ & 75 & 475 & 0.012 \\
FL & June 29 & $1-11<\mathbf{3 0}$ & 713 & 475 & 0.028 \\
FL & Aug. 11 & $1-5<\mathbf{1 5 - 1 6}$ & 739 & 475 & 0.038 \\
FL & Aug. 25 & $11-14<\mathbf{3 5}$ & 810 & 475 & 0.033 \\
\hline
\end{tabular}


Table 4. Summary results of repeated measures ANOVA testing overall differences in mean population retention efficiency of particles between 1-10 $\mu \mathrm{m}$ and across sampling date. Separate ANOVA were conducted for data from the Måkasteinen (MS) and Flørli (FL) sampling sites.

\begin{tabular}{|c|c|c|c|c|c|c|c|}
\hline Site & Effect & SS & $d f$ & MS & $\boldsymbol{F}$ & $\begin{array}{l}\text { G-G / H-F } \\
\text { epsilon }\end{array}$ & \\
\hline MS & Intercept & 2609522 & 1 & 2609522 & 2867 & & 0.001 \\
\hline MS & Date & 193653 & 5 & 38731 & 84 & $0.69 / 0.73$ & $0.001 / 0.001 * / 0.001 * *$ \\
\hline $\mathrm{FL}$ & Intercept & 1299520 & 1 & 1299520 & 2272 & & 0.001 \\
\hline $\mathrm{FL}$ & Date & 112564 & 5 & 526 & 1.8 & $0.67 / 0.71$ & $0.001 / 0.001 * / 0.001 * *$ \\
\hline
\end{tabular}

Table 5. Tukey post hoc test results examining the sites and dates in which retention efficiency of $5 \mu \mathrm{m}$ particles were similar to or significant different from 6-10 $\mu \mathrm{m}$ particles $(R E \mu \mathrm{m})$ at Måkasteinen (MS) and Flørli (FL). ANOVA test results summarized in Table $4 ; p<0.001$. MS is the error term between particle sizes while the error term within date (MS, pooled) was 534 ( $d f$ $1037)$ and $341(d f=1044)$ at MS and FL, respectively.

\begin{tabular}{llllll} 
Site & Date & $\boldsymbol{R E}(\boldsymbol{\mu m})$ & $\boldsymbol{M S}$ & $\boldsymbol{d} \boldsymbol{f}$ & $\boldsymbol{p}$ Tukey \\
\hline MS & May 20 & $5<7-10$ & 203 & 190 & 0.004 \\
MS & June 1 & $5<8-10$ & 504 & 190 & 0.005 \\
MS & June 15 & $5=6-10$ & 1002 & 190 & $n s$ \\
MS & June 29 & $5<7-10$ & 34 & 190 & 0.001 \\
MS & Aug. 10 & $5=6-10$ & 637 & 190 & $n s$ \\
MS & Aug. 24 & $5=6-10$ & 826 & 190 & $n s$ \\
\hline FL & May 19 & $5<9-10$ & 140 & 190 & 0.048 \\
FL & June 2 & $5=6-10$ & 201 & 190 & $n s$ \\
FL & June 14 & $5<7-10$ & 100 & 190 & 0.003 \\
FL & June 29 & $5=6-10$ & 439 & 190 & $n s$ \\
FL & Aug. 11 & $5=6-10$ & 428 & 190 & $n s$ \\
FL & Aug. 25 & $5=6-10$ & 737 & 190 & $n s$ \\
\hline
\end{tabular}


Figures
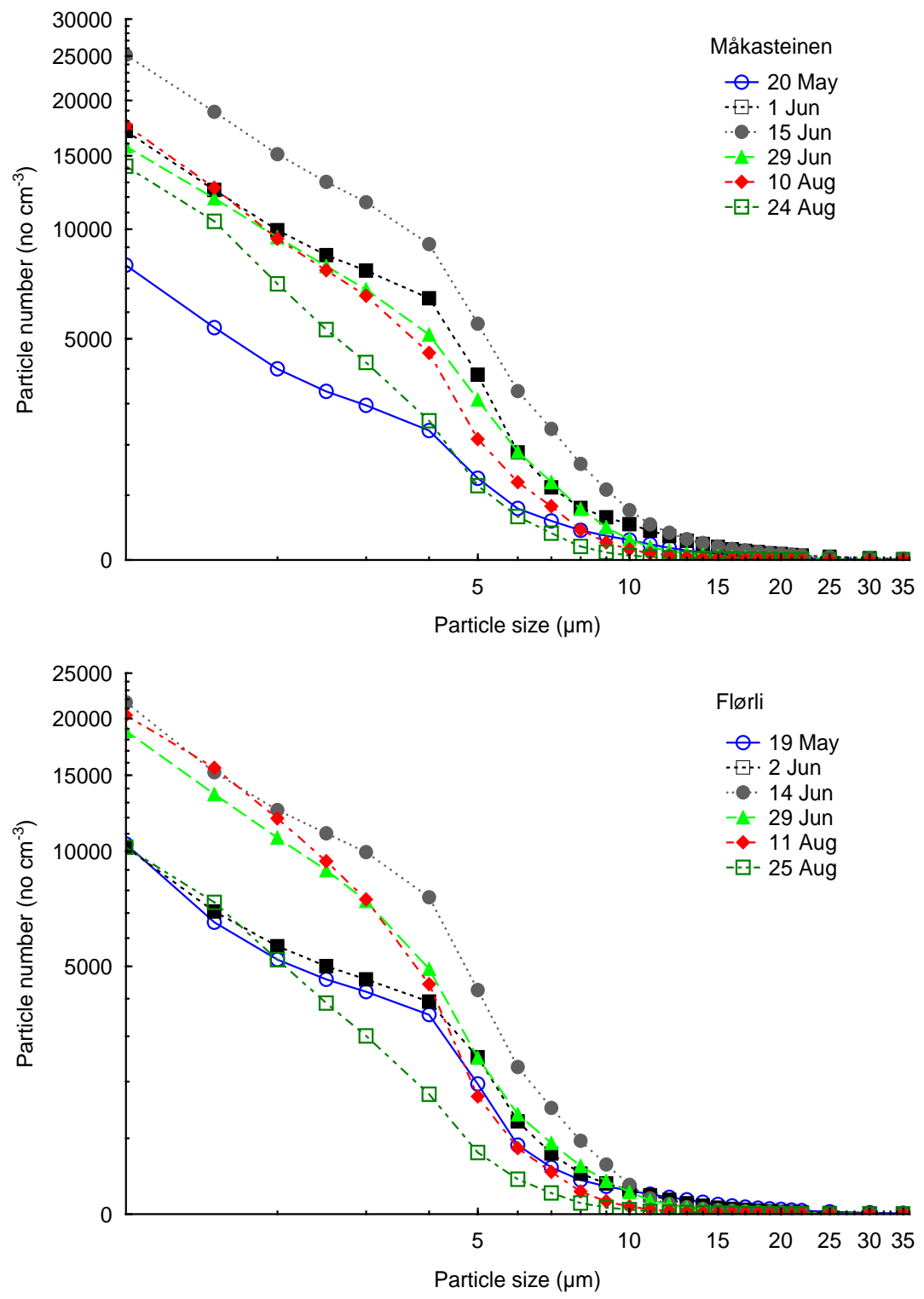

Figure 1. Seasonal changes in natural particle size abundance at $7 \mathrm{~m}$ depth at Måkasteinen (top) and Flørli (bottom). Note the difference in scale value on the $y$-axis. 

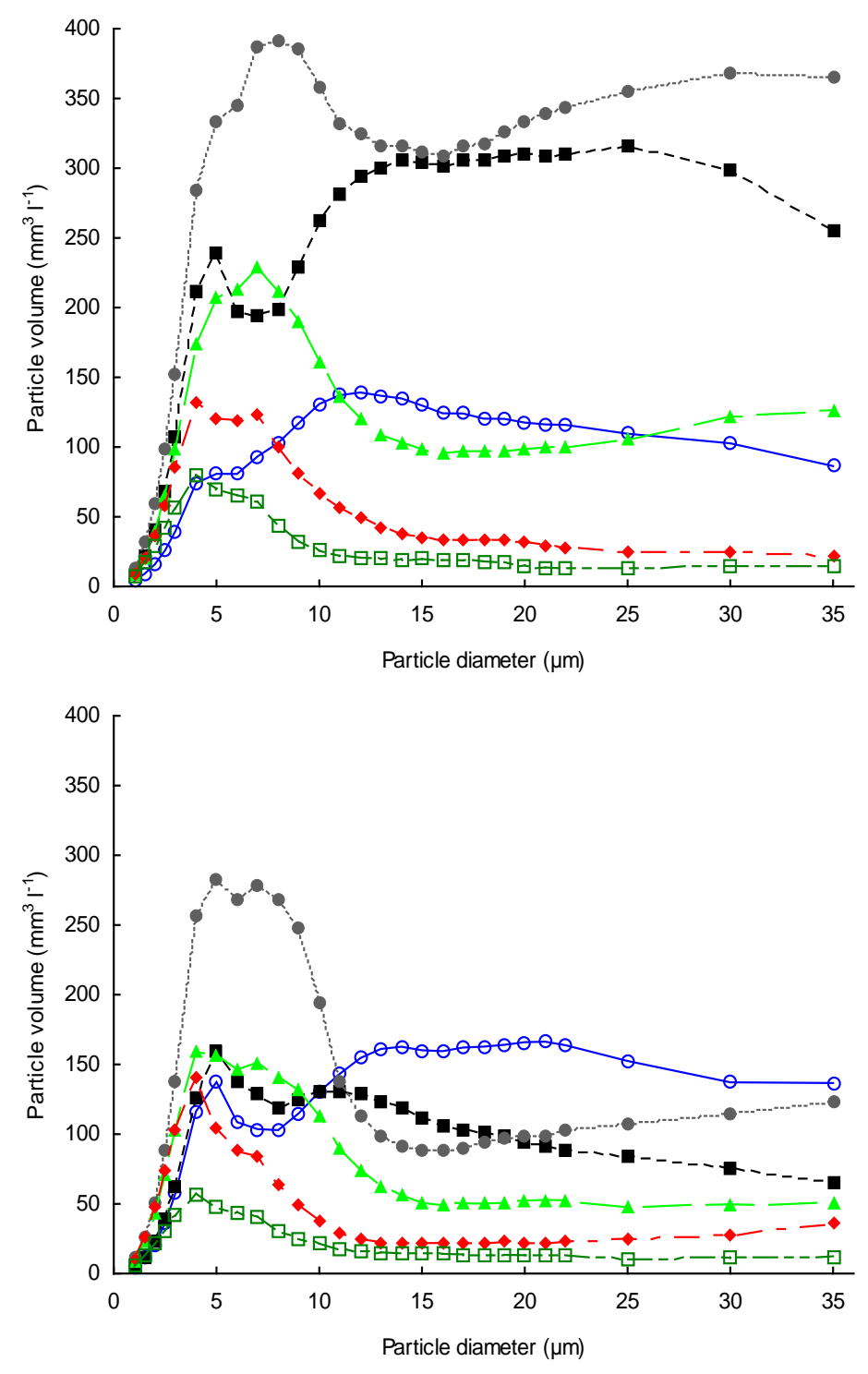

Figure 2. Seasonal changes in the size-distribution of natural particle volumes at $7 \mathrm{~m}$ depth at Måkasteinen (top) and Flørli (bottom). Date corresponds to line layout in figure 1. 

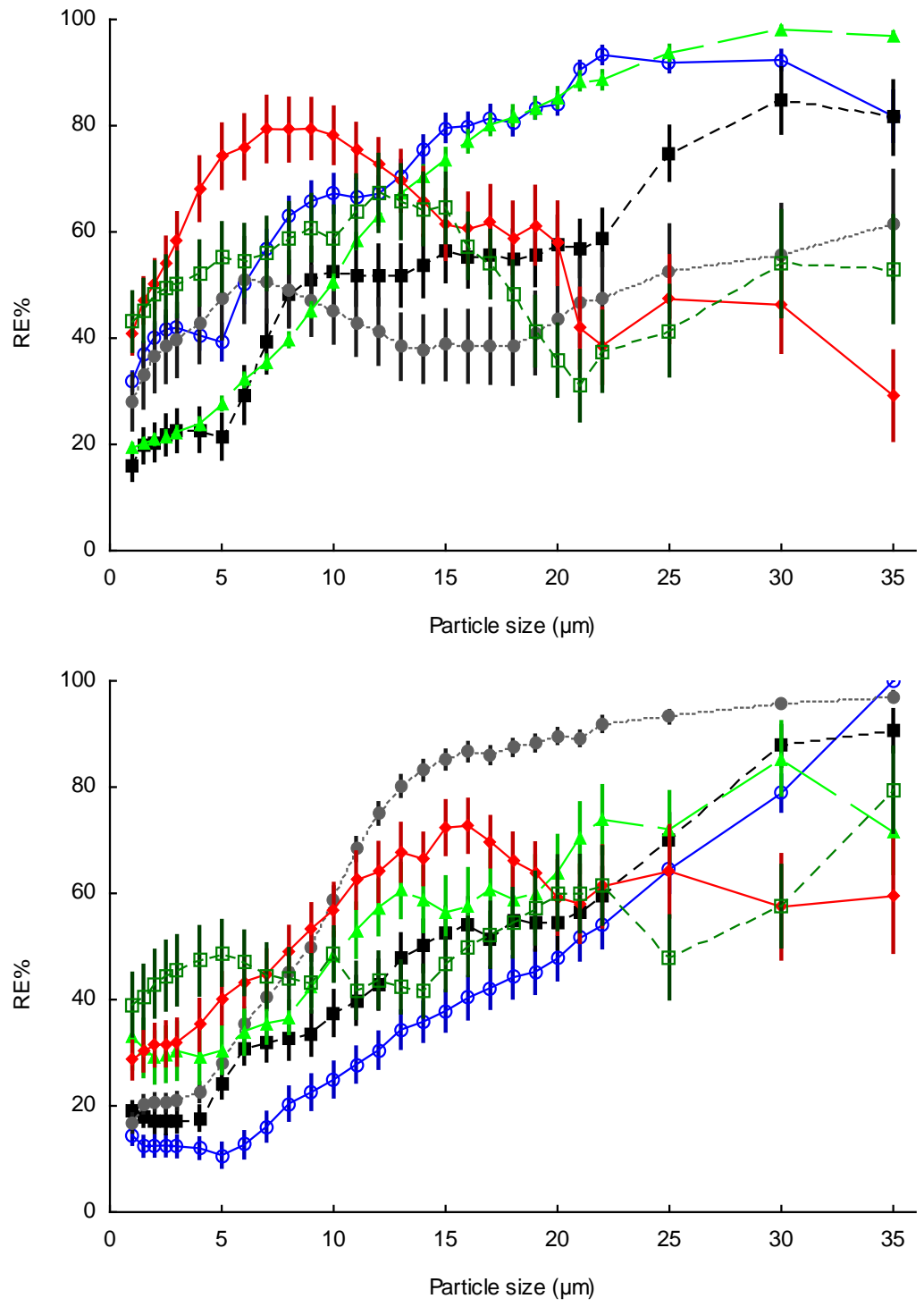

Figure 3. Average ( $\pm 95 \%$ confidence limit; $\mathrm{n}=20)$ standardized retention efficiency $(R E \%)$ of $M$. edulis feeding on natural pelagic particles (Figs. 1 and 2) at Måkasteinen (top) and Flørli (bottom).

Date corresponds

to line layout

in

figure

1. 

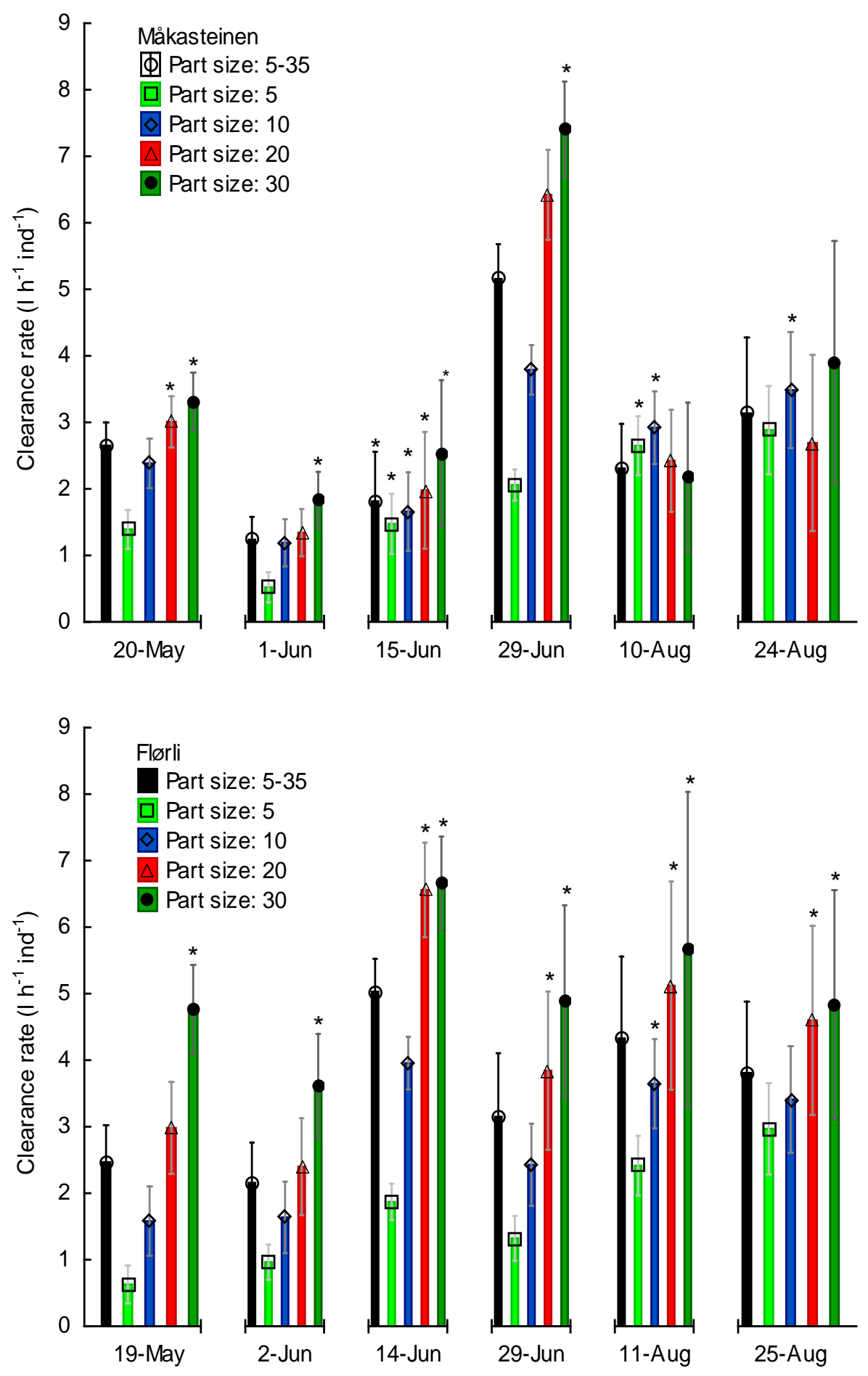

Figure 4. Average clearance rate $\left(\mathrm{h}^{-1}\right)$ of individual $M$. edulis calculated for six different dates in 2010 at Måkasteinen and Flørli. Clearance rate was calculated using particle counts $\left(\mathrm{PC}_{\mathrm{B}}\right.$ and $\mathrm{PC}_{\mathrm{C}}$ in Equation 1) within narrow size ranges (mean $=5,10,20$ and $30 \mu \mathrm{m}$ ) and using average counts across the $5-35 \mu \mathrm{m}$ size range. Error bars are $\pm 95 \%$ confidence limits and the "*" indicates that the measured RE was maximal (Fig. 3). 